\title{
To Be Yourself or to Be Your Ideal Self?
}

\section{Outcomes of Potential Applicants' Actual and Ideal Self-Congruity Perceptions}

Accepted for publication in the Special Issue 'Applicant Behavior' of the Journal of Personnel Psychology. https://doi.org/10.1027/1866-5888/a000213

Journal of Personnel Psychology, 17, 3, () 2018 by Hogrefe Publishing GmbH.

This version of the article may not completely replicate the final version published in Journal of Personnel Psychology. It is not the version of record and is therefore not suitable for citation.

Lien Wille, Department of Personnel Management, Work and Organizational Psychology, Ghent University, Belgium; Greet Van Hoye, Department of Human Resource Management and Organizational Behavior, Ghent University, Belgium; Bert Weijters, Department of Personnel Management, Work and Organizational Psychology, Ghent University, Belgium; Deva Rangarajan, Department of Marketing, Ball State University, Muncie, Indiana (USA); Marieke Carpentier, Department of Human Resource Management and Organizational Behavior, Ghent University, Belgium

Correspondence concerning this paper should be addressed to Lien Wille, Department of Personnel Management, Work and Organizational Psychology, Ghent University, Henri Dunantlaan 2, 9000 Ghent, Belgium. Phone: +32-9-264-94-03. E-mail: Lien.Wille@UGent.be 


\begin{abstract}
Recruitment research on person-organization fit has typically focused on organizations' fit with potential applicants' actual self, not considering other possible self-images. Based on image congruity theory, we investigate how actual and ideal self-congruity relate to application intentions and intentions to spread word-of-mouth. In a first study, conducted in Belgium, actual and ideal self-congruity related positively to both outcomes. The relation with application intentions was equally positive for actual and ideal self-congruity. Ideal selfcongruity showed a stronger positive relation with word-of-mouth intentions. A second study replicated these findings in the United States and tested for social adjustment concern (need to impress others) as a moderator. As social adjustment concern increased, relations of both outcomes with ideal (actual) self-congruity were stronger (weaker).
\end{abstract}

Keywords: Applicant attraction; Actual self-congruity; Ideal self-congruity; Application Intentions; Word-of-mouth 


\section{To Be Yourself or to Be Your Ideal Self?}

\section{Outcomes of Potential Applicants' Actual and Ideal Self-Congruity Perceptions}

More than half of the CEOs express that they worry that a shortage of talented employees may harm the financial success of their organization (Economist Intelligence Unit, 2012). As recruitment identifies and attracts such talent, it fulfills a pivotal human resource function (Derous \& De Fruyt, 2016). However, attracting suitable employees is difficult due to demographic trends that are leading to tight labor markets, such as the shortage of young employees (Beechler \& Woodward, 2009). Given this war for talent, organizations need to be perceived by potential applicants as attractive employers and should stand out from their competitors (Lievens \& Slaughter, 2016).

Prior recruitment research on person-organization fit has shown that potential applicants are more attracted to organizations when they perceive a fit with their own personal characteristics (Uggerslev, Fassina, \& Kraichy, 2012). These studies have, however, typically focused on actual self-congruity or whether potential applicants perceive that their actual self (i.e., the kind of person potential applicants think they are; Beerli, Menses, \& Gil, 2007) matches with the organization's characteristics (see Nolan \& Harold, 2010, for an exception). Yet, image congruity theory (Sirgy, 1982, 1985), a conceptual framework developed in the marketing domain, points out that individuals have multiple self-images that can influence their perceptions and decisions. More specifically, research in marketing has demonstrated that ideal self-congruity is an important factor to take into account in addition to actual self-congruity when trying to understand people's attraction to brands (Malär, Krohmer, Hoyer, \& Nyffenegger, 2011).

There are important parallels between the marketing and recruitment domain. Although the comparison between these two domains might be less appropriate for lowinvolvement products (such as buying a carton of milk), important similarities appear 
between choosing among different employers or jobs and choosing among different consumer brands or high-involvement products (Cable \& Turban, 2001). In both the recruitment and the marketing domain, organizations try to persuade and attract individuals from a relevant target group. These individuals have to choose between multiple possibilities and often possess rather limited information on the offered product or job (Cable \& Turban, 2001). Previous research has successfully applied theories and concepts from marketing research to advance the understanding of recruitment issues (Collins \& Kanar, 2014). Along these lines, we propose that the image congruity theory from the marketing literature can be applied to extend the person-organization fit paradigm within recruitment research.

Applying image congruity theory to a recruitment context, potential applicants may not only be attracted when they perceive a fit between organizations and their actual self, but also their ideal self is likely to play a role (i.e., the kind of person potential applicants would like to be; Beerli et al., 2007). That is, people might not only want to work in organizations that allow them to be themselves, but also in organizations that bring them closer to becoming who they ideally would like to be. Ideal self-congruity is aspirational by definition (i.e., it is something people strive for) and people can be motivated to behave in line with their ideal self to increase their self-esteem and to signal who they want to be (Sirgy, 1982). So far, little is known about how ideal self-congruity might relate to key applicant outcomes, whether these relationships are similar to those observed for actual self-congruity, and whether they may be moderated by individual differences between potential applicants.

Hence, this paper investigates whether both actual and ideal self-congruity relate to potential applicants' intentions to apply to an organization as well as to their intentions to spread positive word-of-mouth. Word-of-mouth is an important source of employment information (Collins \& Stevens, 2002; Van Hoye \& Lievens, 2009), but little is known about its determinants (Van Hoye, 2013). Based on image congruity theory, we propose that people 
will be more willing to apply to an organization and to say positive things to others about the organization when they perceive it to be more similar to their own actual or ideal self-image. Additionally, we explore whether there are differences in the strength of the relationships of actual and ideal self-congruity with these outcomes.

In a first study, we use a Belgian sample to examine these relationships. A second study is conducted to perform a conceptual replication and to test the robustness and generalizability of our findings (Stroebe \& Strack, 2014). We used a different sample from another country, the United States. Furthermore, in line with image congruity theory and research in the marketing domain, we propose that the main relationships examined in Study 1 depend on individual differences. More specifically, in Study 2 we investigate whether actual or ideal self-congruity matter more or less to potential applicants, depending on their need to impress others by associating themselves with particular employers. The need to impress has been labeled "social adjustment concern" (Highhouse, Thornburry, \& Little, 2007). We thus propose that the relations between actual and ideal self-congruity and the recruitment outcomes depend on potential applicants' level of social adjustment concern.

\section{Image Congruity Theory}

The image congruity theory (Sirgy, 1982, 1985) originated in the marketing and consumer behavior literature and has been used to investigate consumer attitudes and intentions towards brands. According to this theoretical framework, consumers hold positive attitudes and intentions toward brands with an image similar to their self-image (i.e., selfcongruity). Consumers with an innovative self-image, for instance, might be more likely to buy Apple than Nokia products as they may perceive Apple as having a more innovative brand personality.

The theory assumes that self-congruity is a multidimensional construct because individuals may have more than one self-image (Kim 2015; Kim \& Hyun, 2013): Individuals 
do not only have an actual self-image (i.e., the kind of person one thinks one is) but also other images, including an ideal self-image (i.e., the kind of person one would like to be), a social self-image (i.e., how one thinks others see oneself) and an ideal social self-image (i.e., how one would like that others see oneself; Beerli et al., 2007). Accordingly, the image congruity theory distinguishes actual self-congruity (i.e., the extent that a brand is similar to one's actual self) from other types of self-congruity, such as ideal self-congruity (i.e., the extent that a brand is similar to one's ideal self). In this study we focus on actual and ideal selfcongruity. These two types of self-congruity have received the most attention in marketing research (Kim \& Hyun, 2013). One reason is that organizations in reality often refer to either actual or ideal self-images in their communications to consumers (Malär et al., 2011). By extension, it is plausible that organizations might use similar approaches in recruitment. Moreover, there is already some initial evidence that actual and ideal self-congruity might also play a role in applicant attraction (Nolan \& Harold, 2010).

Furthermore, the image congruity theory posits that different motives underlie the effects of the different types of self-congruity (Kim, 2015; Kim \& Hyun, 2013). The influence of actual self-congruity would be motivated by self-consistency: consumers choose brands with an image similar to their actual self because they want to protect their personal identity and because it creates a sense of comfort. Ideal self-congruity, on the other hand, would influence outcomes because certain brands might allow consumers to boost their selfesteem by becoming who they would like to be (i.e., self-esteem motive; Sirgy, 1982).

In line with these theoretical assumptions, findings from the meta-analysis of AguirreRodriguez, Bosnjak, and Sirgy (2012) indicate that both actual and ideal self-congruity have robust effects on consumer attitudes, intentions and behaviors towards brands operating within different product or service categories, such as cars, jewelry, and holiday destinations (e.g., Jamal \& Goode, 2001; Kressman et al., 2006; Usakli \& Balogul, 2011). Furthermore, 
self-consistency and self-esteem motives were found to mediate the relations of actual and ideal self-congruity with consumer attitudes, respectively (Sirgy, Johar, \& Claiborne, 1992). Marketing and consumer behavior research thus reveals empirical evidence in support of the image congruity theory.

\section{Person-Organization Fit and Applicant Attraction}

Person-organization fit in a recruitment context is defined as the compatibility between potential applicants and organizations (Kristof, 1996). As noted by Kristof-Brown and Jansen (2007), the most frequently used characteristics to conceptualize personorganization fit are values, needs, and personality. A meta-analysis by Kristof-Brown, Zimmerman, and Johnson (2005) demonstrated that potential applicants with certain personality characteristics are more attracted to organizations with particular characteristics. For instance, potential applicants high in openness/intellect appear to be more attracted to multinational organizations (Lievens, Decaesteker, Coetsier, \& Geirnaert, 2001).

In addition to a fit with objective organization characteristics, applicant attraction also relates to compatibility with organizations' symbolic characteristics (Lievens \& Highhouse, 2003). Examples of such characteristics include the perceived trustworthiness or innovativeness of an organization (Kausel \& Slaughter, 2011). These symbolic characteristics are similar to human personality traits and have been described as "the set of human personality characteristics perceived to be associated with an organization" (Slaughter, Zickar, Highhouse, \& Mohr, 2004, p. 86). Therefore, they have been labeled "employer brand personality". Perceptions of employer brand personality have been found to influence recruitment outcomes such as organizational attractiveness, job pursuit intentions, and wordof-mouth intentions (Lievens \& Highhouse, 2003; Lievens \& Slaughter, 2016; Slaughter et al., 2004; Van Hoye, 2008). 
With respect to the fit with these employer brand personality perceptions, Tom (1971) found that potential applicants preferred organizations when the personality profile of those organizations was more similar to their own personality profile. More recently, research revealed that person-organization fit in terms of specific personality traits may also be relevant to consider. For instance, potential applicants high (vs. low) in conscientiousness appeared to be more attracted to organizations perceived as high on "boy scout", which is an organization personality dimension relating to elements of conscientiousness such as sense of responsibility (Slaughter \& Greguras, 2009).

The studies discussed above only consider actual self-congruity of the applicant (i.e., fit with individuals' actual personality characteristics). As described, based on the image congruity theory, we expect that other types of image-congruity will also influence potential applicants. Specifically, we propose that besides actual self-congruity, ideal self-congruity will play an important role in applicants' application and word-of-mouth intentions. People derive part of their self-concept from their membership or association with certain groups, including the organization they work for (Banks, Kepes, Joshi, \& Seers, 2016). By applying to an organization that is more similar to the actual self-image, applicants might feel they are able to safeguard their self-consistency (Aguirre-Rodriguez et al., 2012). However, when associating oneself with an organization that is more similar to the person one would like to be, applicants might feel they are able to evolve in the direction they want (which might enhance their self-esteem; Kim, 2015). Accordingly, they might not only want to work in organizations where they can be themselves, but also in organizations where they might become who they want to be. In line with these theoretical assumptions, research on employer brand personality suggests that organizations' perceived personality characteristics matter to potential applicants because of their needs for both self-expression and selfenhancement (Highhouse et al., 2007; Lievens \& Highhouse, 2003). Thus, we propose that 
both actual and ideal self-congruity will be positively related to potential applicants' intentions to apply.

To our knowledge, only one study has explored the effects of ideal self-congruity in a recruitment context. Nolan and Harold (2010) found that both actual and ideal self-congruity were positively related to students' perceptions of organizational attractiveness. In the current study, existing organizations with a real employer brand personality were used instead of the fictitious organizations in the Nolan and Harold study (Cable \& Turban, 2001).

Hypothesis 1: Actual (a) and ideal (b) self-congruity will be positively related to application intentions.

However, organizations today are not only concerned with short-term application outcomes, but also with building long-term relationships with potential employees by means of employer branding (Lievens \& Slaughter, 2016). In this context, word-of-mouth plays an important role, as potential applicants are more likely to believe and act upon information received by other people than more company-controlled information (Collins \& Stevens, 2002).

\section{Word-of-Mouth and Self-Congruity}

In a recruitment context, word-of-mouth is defined as communication between two or more people about organizations as employers or about specific jobs, while that communication is not under the direct control of organizations (Van Hoye \& Lievens, 2009). Word-of-mouth can be disseminated by employees (not recruiters) of the organization as well as by people who are not currently employed at the organization. This can involve, for example, being informed by a friend who tells positive or negative things about the company where she did an internship, but also an acquaintance posting a job vacancy on his social media profile (Nikolaou, 2014). Research has shown that word-of-mouth is related to important recruitment outcomes. Several studies have found that positive word-of-mouth has 
strong positive effects on organizations' perceived image and attractiveness as an employer, over and beyond the impact of other sources of employment information (Collins \& Stevens, 2002; Jaidi, Van Hooft, \& Arends, 2011; Van Hoye \& Lievens, 2007, 2009). Research found that, for a large part, these effects can be explained by the high credibility of word-of-mouth, given its interpersonal and non-company-controlled nature (Van Hoye, Weijters, Lievens, \& Stockman, 2016). This is why job seekers tend to put their faith into word-of-mouth more than into job advertisements spread by the organization, especially when they are confronted with contradictory information (Van Hoye \& Lievens, 2007). In the context of employer branding, aligning and managing perceptions of the organization as an employer is of key importance, thus word-of-mouth definitely needs to be taken into account (Lievens \& Slaughter, 2016).

For all these reasons, organizations are trying to stimulate different key target groups, such as employees and potential applicants, to spread positive word-of-mouth about them as an employer. One study examined the underlying reasons for spreading word-of-mouth by current employees (Van Hoye, 2013). She found that job satisfaction, helping job seekers find good jobs, and helping organizations find adequate employees are the most important reasons for sharing positive word-of-mouth. In addition, it was found that providing employees rewards for successful referrals was also (weakly) related with increased word-of-mouth. However, further research demonstrated that rewarding word-of-mouth with financial incentives can drastically reduce its positive impact on potential applicants' perceptions, as its credibility is questioned (Stockman, Van Hoye, \& Carpentier, 2017; Van Hoye et al., 2016). So far, research has tended to focus on the outcomes of word-of-mouth, consequently there is only a limited understanding on how word-of-mouth can be stimulated effectively. Especially little is known about why non-employees share word-of-mouth. 
In the current study, we investigate the relationship of actual and ideal self-congruity with potential applicants' intentions to spread positive word-of-mouth about an organization. Berger (2014) proposed that people share information with others about organizations not only to signal who they are, but also to signal who they would like to be. Consequently, based on the image congruity theory, we expect positive relationships between both actual and ideal self-congruity and intentions to spread word-of-mouth. Sharing positive information with others about an organization that is more congruent with one's actual or ideal self-image might be instrumental in expressing oneself or enhancing one's self-esteem. Along these lines, Van Hoye (2008) found that when nurses held more positive perceptions of their hospital's employer brand personality, they were more inclined to recommend the hospital to others.

Hypothesis 2: Actual (a) and ideal (b) self-congruity will be positively related to word-of-mouth intentions.

\section{Actual Versus Ideal Self-Congruity}

While both actual and ideal self-congruity are expected to relate to application intentions and word-of-mouth intentions, they may do so to a different extent. This is a relevant issue to address, since it has implications for organizations as to what type of selfcongruity they should emphasize in their recruitment communication efforts depending on the desired outcome. Marketing studies found that actual and ideal self-congruity can have different relationships to some outcomes. For example, findings from earlier studies imply that actual self-congruity shows a positive relation with emotional brand attachment, whereas ideal self-congruity relates positively with brand pride (Helm, Renk, \& Mishra, 2016; Malär et al., 2011).

Some researchers have furthermore proposed that different types of self-congruity have differential effects on consumers' attitudes and intentions depending on whether the 
product is consumed publicly or privately (Sirgy, 1982; Graeff, 1996). For instance, Usakli and Baloglu (2011) found that both actual and ideal self-congruity related positively to intentions to return to a travel destination and to recommend it, but actual self-congruity did so to a larger extent for the former and ideal self-congruity for the latter.

Based on these findings, one might expect that also in a recruitment context ideal selfcongruity will relate more strongly to public outcomes. It is, however, not clear whether applying to an organization should be considered a private or a public behavior. The application as such is private, but the potential outcomes of this application (getting a job and working for the company) are public. Significant others will likely know which company a person works for and one can easily communicate to others where one is employed (Highhouse et al., 2007). Regarding word-of-mouth intentions, spreading positive information about an organization as an employer entails making one's ideas about this organization public. This suggests that ideal self-congruity may have a stronger positive relationship with word-of-mouth intentions than actual self-congruity.

In contrast to Hypotheses 1 and 2, our assumptions regarding the differential relations of actual and ideal self-congruity with application intentions and word-of-mouth intentions are mainly based on empirical findings in the marketing literature. Therefore, we formulate exploratory research questions regarding the differential relationship of actual and ideal selfcongruity with potential applicants' intentions to apply and to spread word-of-mouth.

Research Question 1: Are actual and ideal self-congruity differentially related to application intentions?

Research Question 2: Are actual and ideal self-congruity differentially related to word-of-mouth intentions?

In Study 1 we examine Hypotheses 1 and 2 as well as Research Questions 1 and 2. 


\section{Study 1}

\section{Method}

Sample. Using a within-subjects design, a sample of potential applicants completed in 2013 an online Qualtrics survey regarding eight organizations as employers that are wellknown in many countries across the globe (Interbrand, 2012). Participants were 74 postgraduate students enrolled in one or two year business programs at a Belgian university and a business school. They participated in the study on a voluntary basis. As the dataset contains data on eight organizations for 74 participants, we have a total of 592 observations. Age ranged from 20 to 48 years $(M=25.24$ years, $S D=5.63)$ and $54.05 \%$ of the participants were women. A majority of the participants considered actively looking for a job in the next year (i.e., $72.97 \%$ indicated at least a score of 6 on a scale ranging from 0 [very unlikely] to 10 [extremely likely]) and $51.35 \%$ had work experience, demonstrating their relevance as a sample of potential applicants.

Procedure. After a brief introduction and a few questions relating to participants' feelings about their job opportunities to create involvement in answering the survey questions, participants rated how well they knew eight organizations. All organizations were taken from the 2012 Interbrand top 25 (i.e., BMW, Mercedes-Benz, Pepsi, Coca-Cola, Google, Microsoft, Samsung, and Apple; Interbrand, 2012). As all participants were at least somewhat familiar with all organizations (i.e., they indicated 2 or higher on a 5-point scale ranging from 1 [I don't know this company] to 5 [I know this company very well]). They subsequently filled out measures of actual self-congruity, ideal self-congruity, application intentions, and word-of-mouth intentions for each of the eight organizations. The order of these four variables and the order of organizations within each of these variables, was randomized. Also, different scale formats were used to minimize common method variance (Podsakoff, MacKenzie, Lee, \& Podsakoff, 2003). Finally, demographics (i.e., age and 
gender) and background variables (i.e., work experience and job search intentions) were administered. The survey typically took about 11 minutes.

Measures. Self-congruity ratings were preceded by an open-ended question asking participants to take a moment to think about the kind of person they are (would like to be) and to describe their actual (ideal) personality using adjectives/characteristics such as reliable, creative, etc. In this way, we wanted to increase their sense of accountability and motivate them to think about their actual and ideal selves respectively, thus enhancing response quality (Krosnick, 1991). Next, participants were instructed to take a moment to think about how they would describe each organization as a person (it was not asked to write this down). We provided some examples of characteristics that might be used to describe the organization (reliable, creative, energetic, emotional). Finally, following Sirgy et al.'s (1997) advice, self-congruity was measured directly and globally: Participants were asked to indicate to what extent organizations' personalities were similar to the kind of person they are (actual self-congruity) or they would like to be (ideal self-congruity) on a slider scale from 0 (Personality not at all similar to who I am / would like to be) to 100 (Personality completely similar to who I am / would like to be).

Job seekers have only limited resources which they need to divide between different potential employers (such as cognitive resources or time to gather information and to prepare applications; Van Hooft, 2016). Therefore, reflecting the realities of the job search process, application intentions were measured using a constant sum measure. ${ }^{1}$ Participants distributed 100 points across organizations reflecting the effort they would invest in applying to each organization $(0=$ No effort at all would go to this company; $100=$ All my efforts would go to this company).

To measure word-of-mouth intentions (Van Hoye, 2008), participants indicated to what degree they would say positive things about each organization to others using a five-star 
scale $(0=$ No positive things at all; $5=$ A lot of positive things $;$ one item given the withinsubjects design).

\section{Results}

Means, standard deviations, and correlations among study variables are presented in Table 1. This table shows that application intentions and word-of-mouth intentions were rather highly correlated $(r=.64, p<.01)$. However, they still showed a meaningful nonoverlap (59\%). To test our hypotheses and answer our research questions, we structured the data in such a way that each case represents the unique combination of a participant and an organization. Hence the data have a multilevel structure but the higher levels are not nested in one another but they are cross-classified (that is, the observations are nested in organizations and participants). In line with this structure, we used the cross-classified random procedure with the Bayesian estimator in Mplus 7.4, using 4 independent Markov chain Monte Carlo chains with a minimum of 5000 iterations (thinning at every $10^{\text {th }}$ iteration). This procedure takes into account that measurements are repeated within participants and it also accounts for variance across organizations, across individuals, and at the level of organization-individual combinations. The variance decomposition shown in Table 2 indicates that such a multi-level approach is required.

In the model, application intentions and word-of-mouth intentions (dependent variables) were regressed on actual and ideal self-congruity (independent variables) at the within level (i.e., main effects model). Both the dependent and the independent variables were rescaled to have a range from 0 to 10 and were then grand mean centered. ${ }^{2}$ The dependent variables were allowed to freely vary on the between organizational level and the between individual level. In addition, the dependent variables were allowed to freely correlate at both the within level (as we did not expect that the independent variables would fully explain the dependent variables and their correlation) and between individual level (as 
preliminary analyses showed that this covariance term was non-zero).

Table 3 displays the model fit indices, which show a satisfactory fit, and the unstandardized parameter estimates of the proposed relationships.

The first two hypotheses stated respectively that actual and ideal self-congruity would positively relate to application and word-of-mouth intentions. Consistent with Hypotheses $1 \mathrm{a} / \mathrm{b}$, the findings reveal that potential applicants' intention to apply to an organization increased when their actual $(b=0.13,95 \%$ CI $[0.09,0.18])$ and ideal self-congruity $(b=0.14$, 95\% CI $[0.09,0.18])$ increased. Supporting Hypotheses 2a/b, potential applicants also intended to spread more positive word-of-mouth about an organization when their actual $(b=$ $0.18,95 \% \mathrm{CI}[0.10,0.26])$ and ideal self-congruity $(b=0.40,95 \% \mathrm{CI}[0.33,0.47])$ were higher. Regarding the relative strength of the relationships, Research Question 1 asked whether actual and ideal self-congruity relate differently to application intentions. No significant difference was found as actual and ideal self-congruity had an equally positive relationship with potential applicants' intention to apply ( $b_{\text {actual self-congruity }}-b_{\text {ideal self-congruity }}=$ $0.00,95 \%$ CI $[-0.08,0.07])$. Finally, for Research Question 2 regarding the relative relationship of actual and ideal self-congruity with intentions to spread word-of-mouth, we found that ideal self-congruity had a stronger positive relationship with potential applicants' word-of-mouth intentions than actual self-congruity $\left(b_{\text {actual self-congruity }}-b_{\text {ideal self-congruity }}=-0.22\right.$, $95 \%$ CI $[-0.35,-0.09])$.

To test the robustness and generalizability of our findings, we conducted a second study. In this second study we examined our hypotheses in a different sample from another country (i.e., the United States). Additionally, we investigated whether potential applicants' social adjustment concern moderates the relationships of actual and ideal self-congruity with application and word-of-mouth intentions. 


\section{Study 2}

Up until now, we discussed main relationships of actual and ideal self-congruity with recruitment outcomes. However, image congruity theory and research in the marketing literature suggests that the strength of these relationships can differ based on individual difference variables, such as consumers' level of public self-consciousness or self-monitoring (Graeff, 1996; Malär et al., 2011).

In a recruitment context, we propose that social adjustment concern might play a role (DeArmond \& Crawford, 2011; Highhouse et al., 2007). This individual difference variable is defined as "the job seeker's awareness of or interest in the degree to which association with a particular employer invokes prestige or impresses others" (Highhouse et al., 2007, p. 137). According to the theory of symbolic attraction (Highhouse et al., 2007), job seekers feel attracted to certain organizations, because it will allow them to convey to others how they would like to be perceived. This effect is proposed to be stronger for people with a higher motivation to impress others. In line with these theoretical assumptions, potential applicants scoring high on social adjustment concern seem to prefer employer prestige/reputation over other work attributes (Woodard et al., 2016) and put more effort in pursuing jobs at impressive organizations (Highhouse et al., 2007). We argue that people high on social adjustment concern want to present the best possible version of themselves to impress others. This signaling motive is best served by associating themselves with organizations that show congruity with their ideal self, more than their actual self. Potential applicants may thus find their ideal self increasingly more important than their actual self as their level of social adjustment concern increases. Therefore, it can be expected that people who score higher on social adjustment concern will be more strongly inclined to apply to organizations that match their ideal self-image and will be less inclined to apply to organizations that match their actual self-image. For these people, applying for a job at an organization that is more like 
their ideal self-image and less like their current self-image, will allow them to impress others by signaling the best possible version of themselves. The reason for this is that their intentions to apply to the organization are expected to ultimately impact how others perceive them, by actually getting a job at that organization and consequently to be able to associate themselves with that organization (e.g., display your employer on LinkedIn).

Next, the same reasoning applies to the effect on word-of-mouth intentions. People who are more concerned about how others perceive them, may want to be perceived more in line with their ideal self-image than in line with their actual self-image. Therefore, it can be expected that they will be more likely to recommend organizations that are more in line with their ideal self-image and less likely to recommend organizations that are in line with their current actual self-image. The reason is that recommending organizations that are more aligned with their ideal self-image, and hereby associating oneself with these organizations, may make them look good in the eyes of others (Gregory, Munch, \& Peterson, 2002).

In summary, we propose that the relationship of ideal self-congruity with both application intentions and intentions to spread word-of-mouth will be stronger when social adjustment concerns are higher. On the other hand, we propose that the relationship of actual self-congruity with both recruitment outcomes will be weaker, when social adjustment concerns are higher.

Hypothesis 3: Social adjustment concern will moderate the relation of actual selfcongruity with (a) application intentions and (b) word-of-mouth intentions, so that the relation will be less strong when social adjustment concern is higher.

Hypothesis 4: Social adjustment concern will moderate the relation of ideal selfcongruity with (a) application intentions and $(b)$ word-of-mouth intentions, so that the relation will be stronger when social adjustment concern is higher. 
In the second study we examine Hypotheses 1 and 2 as well as Research Questions 1 and 2 (which were also included in Study 1) and we additionally investigate Hypotheses 3 and 4.

\section{Method}

Sample. Our sample consisted of 208 potential applicants from the United States active on MTurk (data were collected in 2016). Prior research has reported similar results for MTurk and non-MTurk samples (Berinsky, Huber, \& Lenz, 2012). Age ranged from 18 to 60 years $(M=30.16$ years, $S D=9.49)$ and $46.15 \%$ were women. Most participants had work experience $(92.80 \%)$ and were employed full-time (62.98\%) or part-time $(20.19 \%)$. A majority was currently looking for a job $(65.38 \%)$ or considered actively looking for a job in the next year (i.e., $75.00 \%$ indicate at least 6 on a scale from 0 [very unlikely] to 10 [extremely likely]).

Procedure and measures. The same procedure and measures as in Study 1 were used, except for application intentions and social adjustment concern. Whereas in Study 1 application and word-of-mouth intentions were measured using a different type of answering scale, application intentions were now measured with a more similar scale to that of wordof-mouth intentions: Participants indicated how much effort they would invest in applying for a job at each organization on a scale from 1 (No effort at all) to 7 (A lot of effort).

Social adjustment concern was measured with a five-item scale from Highhouse et al. (2007) and rated on a 5-point scale (1= Strongly disagree; 5= Strongly agree $)$. An example item is "I wonder if strangers would be impressed by where I work" $(\alpha=.90)$.

\section{Results}

Table 1 presents the means, standard deviations, and correlations among the study variables. To test Hypotheses 1 and 2 and to examine Research Questions 1 and 2 we followed the same analytical procedure as in Study 1. Both application and word-of-mouth 
intentions had variance at each level of analysis (see Table 2) and the main effects model showed acceptable fit (see Table 3).

The parameter estimates in Table 3 show that the results were similar to those of Study 1 . First, application intentions were positively related to actual $(b=0.36,95 \%$ CI $[0.31,0.41])$ and ideal self-congruity $(b=0.41,95 \%$ CI $[0.36,0.46]$, Hypotheses $1 \mathrm{a} / \mathrm{b})$. Second, potential applicants' word-of-mouth intentions increased when their actual $(b=0.23$, $95 \%$ CI $[0.19,0.28])$ and ideal self-congruity $(b=0.40,95 \%$ CI $[0.36,0.44])$ increased (Hypotheses $2 \mathrm{a} / \mathrm{b}$ ). Third, the relation of application intentions with actual self-congruity was not significantly different from its relation with ideal self-congruity ( $b_{\text {actual self-congruity }}-b_{\text {ideal self- }}$ congruity $=-0.05,95 \%$ CI $[-0.14,0.05]$, Research Question 1). Finally, ideal self-congruity showed a stronger positive relation with word-of-mouth intentions than actual self-congruity ( $b_{\text {actual self-congruity }}-b_{\text {ideal self-congruity }}=-0.17,95 \%$ CI [-0.24, -0.09], Research Question 2).

Additionally, we tested whether social adjustment concern moderated the relations of actual and ideal self-congruity with application and word-of-mouth intentions (i.e., moderated model, Hypotheses 3 and 4). We ran a cross-classified model with application and word-of-mouth intentions as dependent variables and actual self-congruity, ideal selfcongruity, and social adjustment concern as independent variables (with the latter independent variable modeled at the between individuals level). Both dependent variables had random intercepts at the between organizations and between individuals levels. The regression slopes (e.g., of application intentions on actual self-congruity) were modeled as random slopes with variance at the between individuals level. Social adjustment concern acted as an antecedent of these random slopes and was modeled as a latent factor at the between individuals level with five indicators and variance fixed to one. This model thus implied a cross-level interaction, with social adjustment concern - at the between individuals level - affecting the regression at the within level. 
The results (see Table 4 and Figure 1) show a significant effect of social adjustment concern on all four random slopes. In support of Hypothesis 3, potential applicants with higher social adjustment concern showed a weaker positive relation of actual self-congruity with application and word-of-mouth intentions. Furthermore, potential applicants higher in social adjustment concern showed a stronger positive relation of ideal self-congruity with application and word-of-mouth intentions, consistent with Hypothesis 4.

\section{Discussion}

Recruitment research on person-organization fit has shown that congruity between applicants and organizations positively affects applicants' perceptions and decisions (e.g., Slaughter \& Greguras, 2009). However, these studies focused on the congruity between an organization and one's actual self, and did not investigate other possible self-images. Our study relies on image congruity theory and contributes to the recruitment literature by investigating potential applicants' perceptions of both actual and ideal self-congruity. Besides intentions to apply, we examined intentions to spread word-of-mouth as an additional important recruitment outcome. Finally, we explored the moderating role of social adjustment concern. Our main findings were similar in the Belgian and U.S. sample, contributing to their robustness and generalizability.

First, our results show that ideal self-congruity in addition to actual self-congruity had a positive relation with potential applicants' intentions to apply, corroborating predictions of the image congruity theory (Sirgy, 1982, 1985). Moreover, ideal and actual self-congruity showed an equally strong relationship with application intentions. These findings suggest that individuals do not only want to work for organizations where they can be themselves, but also for organizations where they may become their ideal self. Along these lines, prior research has indicated that organizations' perceived personality characteristics matter to potential applicants since they want to express and enhance their self-images (Lievens \& 
Highhouse, 2003). Thus, future person-organization fit research should also consider potential applicants' ideal self to completely understand the relationship between fit and applicant attraction.

Second and in line with the image congruity theory (Sirgy, 1982, 1985), actual and ideal self-congruity were positively related to potential applicants' intentions to spread positive word-of-mouth. Moreover, results showed that the relationship with ideal selfcongruity was stronger. This is consistent with research in the marketing domain that showed that consumers were more inclined to recommend products compatible with their ideal self than with their actual self (Usakli \& Baloglu, 2011). Until now little research attention has been devoted to the determinants of spreading positive word-of-mouth in a recruitment context (Van Hoye \& Lievens, 2009). Some findings suggest that intrinsic ways to stimulate word-of-mouth may be more effective than extrinsic means such as providing a monetary referral bonus (Van Hoye et al., 2016). Along these lines, our study suggests that appealing to organizations' congruity with employees' and applicants' ideal selves might be a promising new approach to increase positive word-of-mouth, which should be explored more extensively in future research.

Third, in our second study, the individual difference variable social adjustment concern was included and moderated how actual and ideal self-congruity relate to application and word-of-mouth intentions. As expected, actual self-congruity related weaker and ideal self-congruity stronger to both outcomes as potential applicants were more concerned about impressing others. This finding underlines Highhouse et al.'s (2007) assumption that potential applicants' inferences regarding organizations' personality traits relate differently to outcomes depending on their level of social adjustment concern.

\section{Limitations and Directions for Future Research}


We acknowledge that our study has several limitations. First, so far, most studies that applied image congruity theory focused on the actual and ideal congruity (Kim \& Hyun, 2013). Along these lines, we considered beside potential applicants' actual also ideal selfcongruity. Yet, image congruity theory proposes that other dimensions, namely the social self (i.e., how people think that others perceive them) and the ideal social self (i.e., how people would like others to see them; Beerli et al., 2007) play a role as well. Future research should explore how these other types of self-image relate to applicant attraction. It might also be interesting to look at other types of self-concepts applied outside image congruity theory. Future research might want to link image congruity theory to the self-regulation theory by including the ought self (i.e., how people think they should be; Higgins, 1987). Furthermore, research indicates that cultural differences can influence the role and the strength of certain self-images (Kim \& Hyun, 2013). For example, actual and ideal self-congruity generally show stronger effects in USA samples, but a study using a South-Korean sample found that social types of self-congruity more strongly predicted purchase intentions (Kim \& Hyun, 2013). Future research should thus examine the role of different self-image congruity types in recruitment in other cultures too.

Secondly, our data were cross-sectional, hence we cannot draw causal conclusions regarding the relationships between actual and ideal self-congruity on the one hand and application and word-of-mouth intentions on the other hand. It might be that people who felt more positive about the organization as an employer also rated their congruity with the organization as more positive. Experimental scenario studies manipulating actual and ideal self-congruity and measuring application and word-of-mouth intentions may answer the question of causality. In addition, future research should examine how different types of selfcongruity relate to actual application and recommendation behaviors in addition to the intentions measured in the current study. 
Third, the organizations included in our studies were all organizations that are wellknown in many countries across the globe (Interbrand, 2012, 2016). Our findings may therefore not generalize to small or less familiar organizations. Note, although Nolan and Harold (2010) used fictitious organizations, they found that both actual and ideal selfcongruity related to organizational attractiveness. This might be considered as a sign that some of our results may also apply to less familiar organizations. Future research should verify this.

Fourth, to justify our hypotheses we referred to the underlying mechanisms of selfesteem and self-consistency implied by the image congruity theory (Kim, 2015). However, we did not measure these constructs to test whether these motives actually drive the observed relationships. Consumer behavior research found that both concepts mediated the relations of actual and ideal self-congruity with consumer attitudes (Sirgy et al., 1992). Future research should directly measure these underlying mechanisms in a recruitment context as well.

\section{Practical Implications}

Our findings suggest that organizations should not only focus on the fit between potential applicants' actual self and organizations' perceived personality, but also on the compatibility with potential applicants' ideal self because both types of self-congruity are positively related to potential applicants' intentions. In addition, organizations may want to emphasize different types of self-congruity in their recruitment communication depending on what they want to achieve. When their goal is to convince potential applicants to apply, they may highlight both actual and ideal self-congruity. However, it may be more efficient to predominantly underscore ideal self-congruity when organizations want to motivate potential applicants to spread positive word-of-mouth, given the war for talent they are engaged in. Future research should investigate how organizations can effectively emphasize ideal selfcongruity in their recruitment and branding efforts. One possibility could be by focusing on 
how training and development opportunities allow employees to become who they would like to be.

\section{Conclusion}

Our findings suggest that potential applicants' perceptions of both actual and ideal self-congruity relate positively to their application intentions. Intentions to spread positive word-of-mouth relate most strongly to ideal self-congruity. As potential applicants' level of social adjustment concern increases, ideal self-congruity seems to be more important than actual self-congruity. Consequently, future studies should also consider potential applicants' ideal self when investigating the effects of person-organization fit. 


\section{References}

Aguirre-Rodriguez, A., Bosnjak, M., Sirgy, M. J. (2012). Moderators of the self-congruity effect on consumer decision-making: A meta-analysis. Journal of Business Research, 65, 1179-1188. doi: 10.1016/j.jbusres.2011.07.031

Banks, G. C., Kepes, S., Joshi, M. and Seers, A. (2016). Social identity and applicant attraction: Exploring the role of multiple levels of self. Journal of Organizational Behavior, 37, 326-345. doi: 10.1002/job.2043

Beechler, S., \& Woodward, I. C. (2009). The global "war for talent". Journal of International Management, 15, 273-285. doi: 10.1016/j.intman.2009.01.002

Beerli, A., Menses, G. D., \& Gil, S. M. (2007). Self-congruity and destination choice. Annals of Tourism Research, 34, 571-587. doi: 10.1016/j.annals.2007.01.005

Berger, J. (2014). Word of mouth and interpersonal communication: A review and directions for future research. Journal of Consumer Psychology, 24, 586-607. doi: 10.1016/j.jcps.2014.05.002

Berinksy, A. J., Huber, G. A., \& Lenz, G. S. (2012). Evaluating online labour markets for experimental research: Amazon.com's Mechanical Turk. Political Analysis, 20, 351368. doi: 10.1093/pan/mpr057

Cable, D. M., \& Turban, D. B. (2001). Establishing the dimensions, sources, and value of job seekers' employer knowledge during recruitment. Research in Personnel and Human Resources Management, 20, 115-164.

Collins, C. J., \& Kanar, A. M. (2014). Employer brand equity and recruitment research. In K. Y. T. Yu \& D. M. Cable (Eds.), The Oxford handbook of recruitment (pp. 284-297). New York: Oxford University Press. doi:10.1093/oxfordhb/9780199756094.013.0016

Collins, C. J., \& Stevens, C. K. (2002). The relationship between early recruitment-related activities and the application decisions of new labor-market entrants: A brand equity 
approach to recruitment. Journal of Applied Psychology, 87, 1121-1133. doi: 10.1037/0021-9010.87.6.1121

DeArmond, S., \& Crawford, E. C. (2011). Organization personality perceptions and attraction: The role of social identity consciousness. International Journal of Selection and Assessment, 19, 405-414.

Derous, E., \& De Fruyt, F. (2016). Developments in recruitment and selection research. International Journal of Selection and Assessment, 24, 1-3. doi: 10.1111/ijsa.12123

Economist Intelligence Unit (2012). CEO perspectives: How HR can take on a bigger role in driving growth. Retrieved from www.lancaster.ac.uk

Graeff, T. R. (1996). Image congruence effects on product evaluations: The role of selfmonitoring and public/private consumption. Psychology \& Marketing, 13, 481-499. doi: 10.1002/(SICI)1520-6793(199608)13:5<481::AID-MAR3>3.0.CO;2-5

Gregory, G. D., Munch, J. M. \& Peterson, M. (2002). Attitude functions in consumer research: Comparing value-attitude relations in individualist and collectivist cultures. Journal of Business Research, 55, 933-942.

Helm, S. V., Renk, U., \& Mishra, A. (2016). Exploring the impact of employees' self concept, brand identification and brand pride on brand citizenship behaviors. European Journal of Marketing, 50, 58-77. doi: 10.1108/EJM-03-2014-0162

Higgins, E. T. (1987). Self-discrepancy - a theory relating self and affect. Psychological Review, 94, 319-340. doi: 10.1037//0033-295x.94.3.319

Highhouse, S., Thornbury, E. E., \& Little, I. S. (2007). Social-identity functions of attraction to organizations. Organizational Behavior and Human Decision Processes, 103, 134146. doi: 10.1016/j.obhdp.2006.01.001

Interbrand (2012). Best global brands 2012 rankings. Retrieved from http://interbrand.com/best-brands/best-global-brands/2012/ranking/ 
Interbrand (2016). Best global brands 2016 rankings. Retrieved from http://interbrand.com/best-brands/best-global-brands/2016/ranking/

Jaidi, Y., Van Hooft, E. A. J., \& Arends, L. R. (2011). Recruiting highly educated graduates: A study on the relationship between recruitment information sources, the theory of planned behavior, and actual job pursuit. Human Performance, 24, 135-157. doi: $10.1080 / 08959285.2011 .554468$

Jamal, A., \& Goode, M. M. H. (2001). Consumers and brands: a study of the impact of selfimage congruence on brand preference and satisfaction. Marketing Intelligence \& Planning, 19, 482-492. doi:10.1108/02634500110408286

Kausel, E. E., \& Slaughter, J. E. (2011). Narrow personality traits and organizational attraction: Evidence for the complementary hypothesis. Organizational Behavior and Human Decision Processes, 114, 3-14. doi: 10.1016/j.obhdp.2010.08.002

Kim, J. (2015). Self-congruity effects: A critical review and an integrative model. Japanese Psychological Research, 57, 348-362. doi: 10.1111/jpr.12084

Kim, J., \& Hyun, Y. J. (2013). The importance of social and ideal social dimensions in selfcongruity research. Asian Journal of Social Psychology, 16, 39-49. doi: 10.1111/ajsp.12003

Kressmann, F., Sirgy, M. J., Herrmann, A., Huber, F., Huber, S., \& Lee, D.-J. (2006). Direct and indirect effects of self-image congruence on brand loyalty. Journal of Business Research, 59, 955-964. doi:10.1016/j.jbusres.2006.06.001

Kristof, A. L. (1996). Person-organization fit: An integrative review of its conceptualizations, measurement, and implications. Personnel Psychology, 49, 1-49. doi: 10.1111/j.17446570.1996.tb01790.x 
Kristof-Brown, A. L., \& Jansen, K. J. (2007). Issues of person-organization fit. In C. Ostroff \& T. A. Judge (Eds.), Perspectives on Organizational Fit (pp. 123-153). New York: Lawrence Erlbaum.

Kristof-Brown, A. L., Zimmerman, R. D., \& Johnson, E. C. (2005). Consequences of individuals' fit at work: A meta-analysis of person-job, person-organization, persongroup, and person-supervisor fit. Personnel Psychology, 58, 281-342. doi: 10.1111/j.1744-6570.2005.00672.x

Krosnick, J. A. (1991). Response strategies for coping with the cognitive demands of attitude measures in surveys. Applied Cognitive Psychology, 5, 213-236. doi: 10.1002/acp.2350050305

Lievens, F., Decaesteker, C., Coetsier, P., \& Geirnaert, J. (2001). Organizational attractiveness for prospective applicants: A person-organization fit perspective. Applied Psychology: An International Review, 50, 30-51. doi: 10.1111/14640597.00047

Lievens, F., \& Highhouse, S. (2003). The relation of instrumental and symbolic attributes to a company's attractiveness as an employer. Personnel Psychology, 56, 75-102. doi: 10.1111/j.1744-6570.2003.tb00144.x

Lievens, F., Van Hoye, G., \& Anseel, F. (2007). Organizational identity and employer image: Towards a unifying framework. British Journal of Management, 18, S45-S59. doi: $10.1111 / \mathrm{j} .1467-8551.2007 .00525 . x$

Lievens, F., \& Slaughter, J. E. (2016). Employer image and employer branding: What we know and what we need to know. Annual Review of Organizational Psychology and Organizational Behavior, 3, 407-440. doi: 10.1146/annurev-orgpsych-041015-062501 
Malär, L., Krohmer, H., Hoyer, W. D., \& Nyffenegger, B. (2011). Emotional brand attachment and brand personality: The relative importance of the actual and the ideal self. Journal of Marketing, 75, 35-52. doi: 10.1509/jmkg.75.4.35

Nikolaou, I. (2014). Social networking web sites in job search and employee recruitment. International Journal of Selection and Assessment, 22, 179-189. doi: 10.1111/ijsa. 12067

Nolan, K. P., \& Harold, C. M. (2010). Fit with what? The influence of multiple self-concept images on organizational attraction. Journal of Occupational and Organizational Psychology, 83, 645-662. doi: 10.1348/096317909X465452

Podsakoff, P. M., MacKenzie, S. B., Lee, J.-Y., \& Podsakoff, N. P. (2003). Common method biases in behavioral research: A critical review of the literature and recommended remedies. Journal of Applied Psychology, 88, 879-903. doi: 10.1037/00219101.88.5.879

Sirgy, M. J. (1982). Self-image/product-image congruity and advertising strategy. In V. Kothari (Ed.), Developments in Marketing Science (Vol 5, pp. 129-133). Marquette, MI: Academy of Marketing Science.

Sirgy, M. J. (1985). Using self-congruity and ideal congruity to predict purchase motivation. Journal of Business Research, 13, 195-206. doi: 10.1016/0148-2963(85)90026-8

Sirgy, M. J., Grewal, D., Mangleburg, T. F., Park, J., Chon, K. S., Claiborne, C. B., Johar, J. S., \& Berkman, H. (1997). Assessing the predictive validity of two methods of measuring self-image congruence. Journal of the Academy of Marketing Science, 25, 229-241. doi: 10.1177/0092070397253004

Sirgy, M. J., Johar, J. S., \& Claiborne, C. B. (1992). Self-concept motivation as mediator between self-image congruence and attitude/intention. In V. L. Critten (Ed.), 
Developments in Marketing Science: Proceedings of the Academy of Marketing Science (pp. 402-406). Chestnut Hill, MA: Academy of Marketing Science.

Sirgy, M. J., Lee, D. J., Johar, J. S. and Tidwell, J. (2008). Effect of self-congruity with sponsorship on brand loyalty. Journal of Business Research, 61, 1091-1097. doi: 10.1016/j.jbusres.2007.09.022

Slaughter, J. E., Zickar, M. J., Highhouse, S., \& Mohr, D. C. (2004). Personality trait inferences about organizations: Development of a measure and assessment of construct validity. Journal of Applied Psychology, 89, 85-103.

Slaughter, J. E., \& Greguras, G. J. (2009). Initial attraction to organizations: The influence of trait inferences. International Journal of Selection and Assessment, 17, 1-18: doi: 10.1111/j.1468-2389.2009.00447.x

Stockman, S., Van Hoye, G., \& Carpentier, M. (2017). The dark side of employee referral bonus programs: Potential applicants' awareness of a referral bonus and perceptions of organisational attractiveness. Applied Psychology: An International Review, 66, 599627. doi:10.1111/apps. 12100

Stroebe, W., \& Strack, F. (2014). The alleged crisis and the illusion of exact replication, Perspectives on Psychological Science, 9, 59-71. doi: 10.1177/1745691613514450

Tom, V. R. (1971). The role of personality and organizational images in the recruitment process. Organizational Behavior and Human Performance, 6, 573-592.

Uggerslev, K. L., Fassina, N. E., \& Kraichy, D. (2012). Recruiting through the stages: A meta-analytic test of predictors of applicant attraction at different stages of the recruiting process. Personnel Psychology, 65, 597-660. doi: 10.1111/j.17446570.2012.01254.x 
Usakli, A., \& Baloglu, S. (2011). Brand personality of tourist destinations: An application of self-congruity theory. Tourism Management, 32, 114-127. doi: 10.1016/j.tourman.2010.06.006

Van Hooft, E. A. J. (2016). Self-regulatory perspectives in the theory of planned job search behavior. In Klehe, U. \& van Hoofdt, E.A.J. (Eds.), Oxford Handbooks Online. Oxford University Press. doi:10.1093/oxfordhb/9780199764921.013.31

Van Hoye, G. (2008). Nursing recruitment: Relationship between perceived employer image and nursing employees' recommendations. Journal of Advanced Nursing, 63, 366375. doi: 10.1111/j.1365-2648.2008.04710.x

Van Hoye, G. (2013). Recruiting through employee referrals: An examination of employees' motives. Human Performance, 26, 451-464. doi:10.1080/08959285.2013.836199

Van Hoye, G., \& Lievens, F. (2007). Social influences on organizational attractiveness: Investigating if and when word-of-mouth matters. Journal of Applied Social Psychology, 37, 2024-2047. doi: 10.1111/j.1559-1816.2007.00249.x

Van Hoye, G., \& Lievens, F. (2009). Tapping the grapevine: A closer look at word-of-mouth as a recruitment source. Journal of Applied Psychology, 94, 341-352. doi: $10.1037 / \mathrm{a} 0014066$

Van Hoye, G., Weijters, B., Lievens, F., \& Stockman, S. (2016). Social influences in recruitment: When is word-of-mouth most effective? International Journal of Selection and Assessment, 24, 42-53. doi: 10.1111/ijsa.12128

Woodard, M. S., Miller, J. K., Miller, D. J., Silvernail, K. D., Guo, C., Nair, S., Aydin, M. D., Lemos, A. H. D., Donnelly, P. F., Kumpikaite-Valiuniene, V., Marx, R., \& Peters, L. M. (2016). A cross-cultural examination of preferences for work attributes. Journal of Managerial Psychology, 31, 702-719. doi: 10.1108/JMP-09-2013-0289 


\section{Footnotes}

${ }^{1}$ Using a distributional measure causes the variable to be distributed similarly to a variable that has been standardized at the between-subjects level. That is, it reduces the between-subjects variance to zero (apart from rounding errors), as also reported in the variance decomposition in Table 2. Since the regression model of interest is estimated entirely at the within-level (level 1), the use of a distributional measure is not an issue in interpreting our findings.

${ }^{2}$ Since the data have a cross-classified structure and there is no commonly accepted/default way of standardizing results, unstandardized results are reported. To enhance the comparability of the parameter estimates, we applied this transformation to the data. 


\section{Table 1}

Means, Standard Deviations, and Correlations among Variables in Study 1 (above the diagonal) and Study 2 (below the diagonal)

\begin{tabular}{|c|c|c|c|c|c|c|c|c|c|c|c|c|}
\hline & \multicolumn{2}{|c|}{ Study 1} & \multicolumn{2}{|c|}{ Study 2} & \multicolumn{8}{|c|}{ Correlations } \\
\hline & $\mathrm{M}$ & SD & $\mathrm{M}$ & SD & 1 & 2 & 3 & 4 & 5 & 6 & 7 & 8 \\
\hline 1. Age (years) & 25.24 & 5.59 & 30.17 & 9.48 & & .14 & -.16 & .04 & .04 & .06 & .02 & -.12 \\
\hline 2. Female $(0=\mathrm{M}, 1=\mathrm{F})$ & .54 & .50 & .46 & .50 & -.21 & & -.17 & .02 & .09 & .03 & .11 & .03 \\
\hline 3. Brand familiarity & 3.62 & .93 & 3.81 & 1.03 & -.04 & .01 & & .30 & .26 & .23 & .23 & .11 \\
\hline 4. Application intentions & 12.50 & 12.47 & 5.01 & 1.80 & .00 & .00 & .22 & & .64 & .55 & .62 & .19 \\
\hline 5. WOM intentions & 3.06 & 1.18 & 3.51 & 1.15 & -.07 & -.03 & .37 & .46 & & .57 & .65 & .21 \\
\hline 6. Actual self-congruity & 52.34 & 24.60 & 54.31 & 27.40 & -.02 & -.11 & .26 & .41 & .49 & & .64 & .26 \\
\hline 7. Ideal self-congruity & 55.01 & 25.12 & 60.70 & 27.32 & -.13 & -.02 & .28 & .43 & .60 & .54 & & .31 \\
\hline 8. SAC & & & 3.21 & .97 & & & & & & & & \\
\hline
\end{tabular}

Note. Correlations with $p<.01$ are printed in boldface. Sample sizes are $\mathrm{N}_{\text {study } 1}=592$ observations (for $\mathrm{N}=74$ respondents) and $\mathrm{N}_{\text {study } 2}=1664$ observations (for $\mathrm{N}=208$ respondents). Brand familiarity was rated on a five-point scale $(0=I$ don't know this company, $5=I$ know this company very well $)$. Application intentions were measured with a constant sum measure $(0=$ No effort at all would go to this company; $100=$ All my efforts would go to this company) in Study 1 and with a 7 -point Likert scale $(1=$ No effort at all; $7=$ Very much effort) in Study 2. Word-of-mouth intentions (WOM intentions) were rated on a five-star scale ( $0=$ No positive things at all; $5=$ A lot of positive things)Actual and ideal self-congruity were measured on a 100 point slider scale $(0=$ Personality not at all similar to who I am / would like to be; $100=$ Personality completely similar to who I am / would like to be). Social adjustment concern (SAC) was rated on a scale from 1 (Strongly disagree) to 5 (Strongly agree). 


\section{Table 2}

Variance Decomposition of Application and Word-of-Mouth Intentions in Study 1 and Study 2

\begin{tabular}{|c|c|c|c|c|c|c|c|c|c|}
\hline & & \multicolumn{4}{|c|}{ Study 1} & \multicolumn{4}{|c|}{ Study 2} \\
\hline & & \multirow[b]{3}{*}{ Pct. } & \multirow[b]{3}{*}{ Est. } & \multicolumn{2}{|c|}{ 95\% C.I. } & \multirow[b]{3}{*}{ Pct. } & \multirow[b]{3}{*}{ Est. } & \multicolumn{2}{|c|}{ 95\% C.I. } \\
\hline & & & & Lower & Upper & & & Lower & Upper \\
\hline & & & & bound & bound & & & bound & bound \\
\hline \multirow[t]{4}{*}{ Application intentions } & Within Level & $81 \%$ & 1.45 & 1.29 & 1.63 & $42 \%$ & 4.57 & 4.25 & 4.92 \\
\hline & Between organizations & $18 \%$ & 0.33 & 0.08 & 2.34 & $25 \%$ & 2.73 & 0.81 & 9.21 \\
\hline & Between individuals & $0 \%$ & 0.01 & 0.00 & 0.03 & $32 \%$ & 3.50 & 2.82 & 4.41 \\
\hline & Total & $100 \%$ & 1.78 & 1.48 & 3.80 & $100 \%$ & 10.80 & 8.65 & 7.20 \\
\hline \multirow[t]{4}{*}{ Word-of-mouth intentions } & Within Level & $57 \%$ & 3.94 & 3.49 & 4.45 & $53 \%$ & 3.23 & 3.00 & 3.48 \\
\hline & Between organizations & $28 \%$ & 1.92 & 0.55 & 3.30 & $18 \%$ & 1.09 & 0.33 & 7.34 \\
\hline & Between individuals & $15 \%$ & 1.04 & 0.63 & 1.68 & $29 \%$ & 1.73 & 1.35 & 2.21 \\
\hline & Total & $100 \%$ & 6.90 & 5.34 & 8.39 & $100 \%$ & 6.04 & 5.11 & 2.25 \\
\hline
\end{tabular}

Note. The between individuals variance of application intentions in Study 1 is zero as we used a distributional measure for that variable. Such a measure causes the variable to be distributed similarly to a variable that has been standardized at the between individuals level. 
Table 3

Parameter Estimates of the Main Effects Model in Study 1 and Study 2

\begin{tabular}{|c|c|c|c|c|c|c|c|c|c|}
\hline & \multirow[b]{4}{*}{ Label } & \multirow[b]{4}{*}{ Dependent variable } & \multirow[b]{4}{*}{ Independent variable } & \multicolumn{3}{|c|}{ Study 1} & \multicolumn{3}{|c|}{ Study 2} \\
\hline & & & & & \multicolumn{2}{|c|}{ 95\% C.I. } & \multirow[b]{3}{*}{ Est. } & \multicolumn{2}{|c|}{ 95\% C.I. } \\
\hline & & & & & Lower & Upper & & Lower & Upper \\
\hline & & & & Est. & bound & bound & & bound & bound \\
\hline Parameter & B1 & Application intentions & Actual self-congruity & 0.13 & 0.09 & 0.18 & 0.36 & 0.31 & 0.41 \\
\hline \multirow[t]{3}{*}{ estimates } & $\mathrm{B} 2$ & & Ideal self-congruity & 0.14 & 0.09 & 0.18 & 0.41 & 0.36 & 0.46 \\
\hline & B3 & Word-of-mouth intentions & Actual self-congruity & 0.18 & 0.10 & 0.26 & 0.23 & 0.19 & 0.28 \\
\hline & B4 & & Ideal self-congruity & 0.40 & 0.33 & 0.47 & 0.40 & 0.36 & 0.44 \\
\hline Parameter & $\mathrm{B} 1-\mathrm{B} 2$ & & & 0.00 & -0.08 & 0.07 & -0.05 & -0.14 & 0.05 \\
\hline differences & B3 - B4 & & & -0.22 & -0.35 & -0.09 & -0.17 & -0.24 & -0.09 \\
\hline \multirow[t]{2}{*}{$R^{2}$} & & Application intentions & & 0.23 & 0.17 & 0.30 & 0.56 & 0.53 & 0.60 \\
\hline & & Word-of-mouth intentions & & 0.37 & 0.30 & 0.44 & 0.56 & 0.52 & 0.59 \\
\hline
\end{tabular}

Note. The parameter estimates are unstandardized regression coefficients

Model fit (12 free parameters): Study 1, Bayesian Posterior Predictive $p$-value $=.352$ (diff. observed vs. replicated chi² 95\% C.I. $=[-14.941,24.431] ;$ DIC $=4104.566$ (pD = 72.005); Study 2, Bayesian Posterior Predictive $p$-value $=.432$ (diff. observed vs. replicated chi² 95\% C.I. $=[-15.938,19.725]$; DIC $=12156.813$ (pD $=359.304$ ). 
Table 4

Parameter Estimates of the Moderation by Social Adjustment Concern in Study 2

\begin{tabular}{|c|c|c|c|c|c|c|c|}
\hline \multirow[t]{3}{*}{ Label } & \multirow[t]{4}{*}{ Dependent variable } & \multirow[t]{4}{*}{ Independent variable } & \multirow[t]{4}{*}{$R^{2}$} & \multirow[t]{4}{*}{ Intercept } & \multicolumn{3}{|c|}{ Slope } \\
\hline & & & & & & \multicolumn{2}{|c|}{$95 \%$ C. I. } \\
\hline & & & & & & Lower & Upper \\
\hline & & & & & Est. & bound & bound \\
\hline B1 & Application intentions & Actual self-congruity & $24 \%$ & 0.38 & -0.15 & -0.23 & -0.08 \\
\hline $\mathrm{B} 2$ & & Ideal self-congruity & $10 \%$ & 0.38 & 0.09 & 0.01 & 0.16 \\
\hline B3 & Word-of-mouth intentions & Actual self-congruity & $27 \%$ & 0.25 & -0.07 & -0.13 & -0.02 \\
\hline B4 & & Ideal self-congruity & $7 \%$ & 0.41 & 0.06 & 0.003 & 0.12 \\
\hline
\end{tabular}

Note. The moderating effect of social adjustment concern on the relationship between the independent and dependent variable is reflected by the estimate and the $95 \%$ confidence interval. 


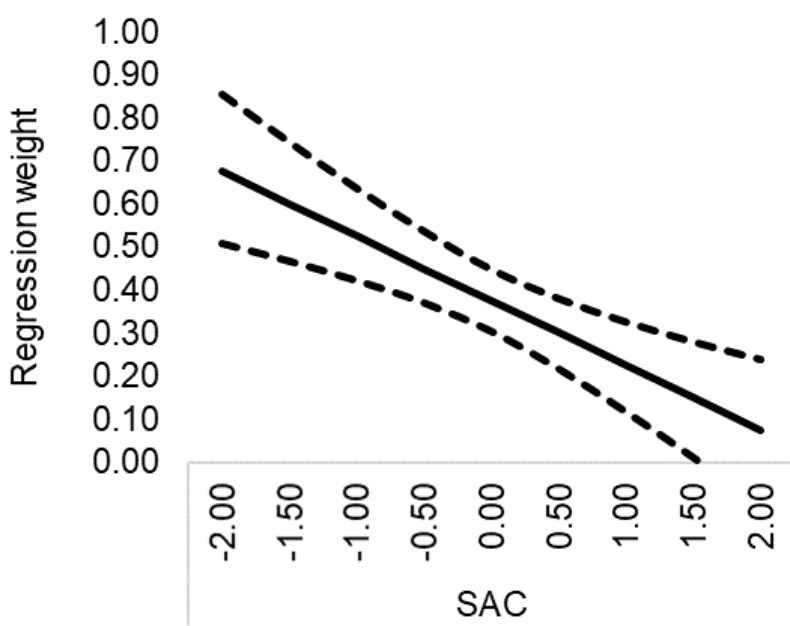

(A) DV = Application intentions and IV = Actual self-congruity

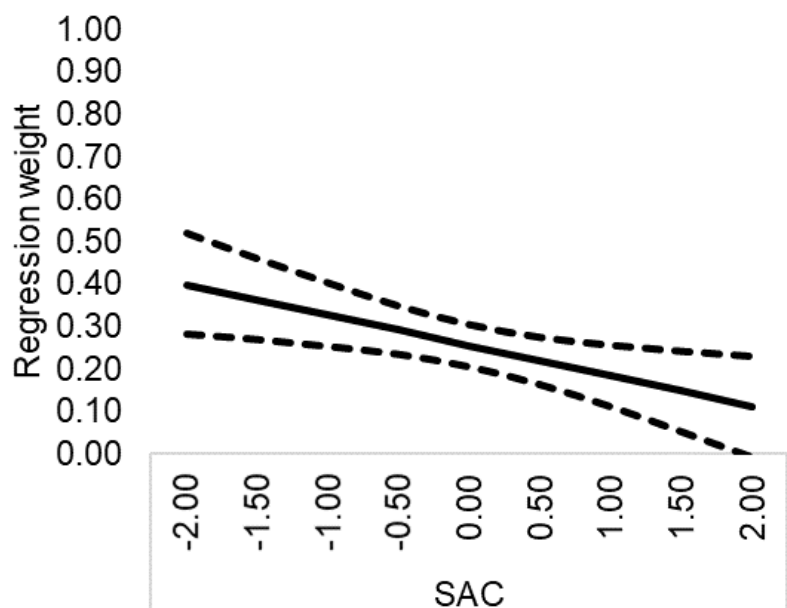

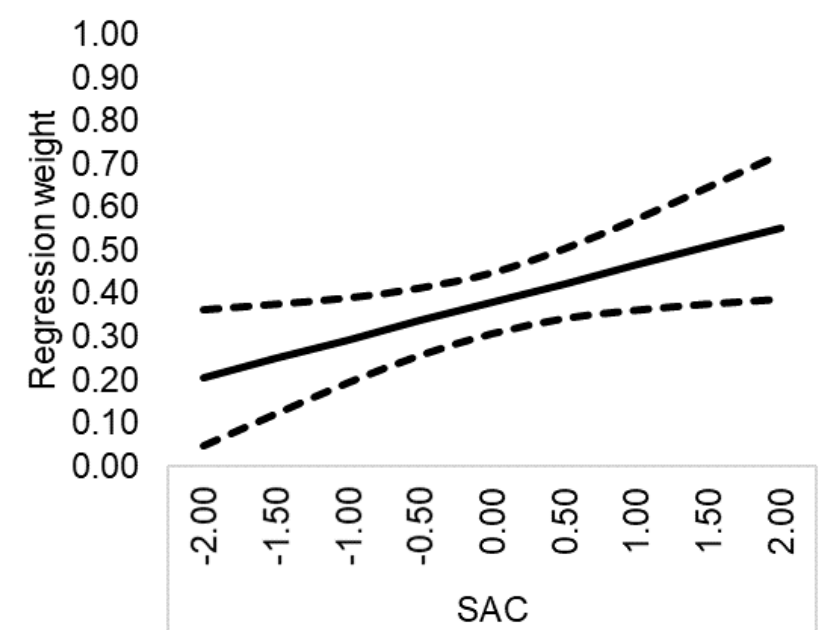

(B) DV = Application intentions and IV = Ideal self-congruity

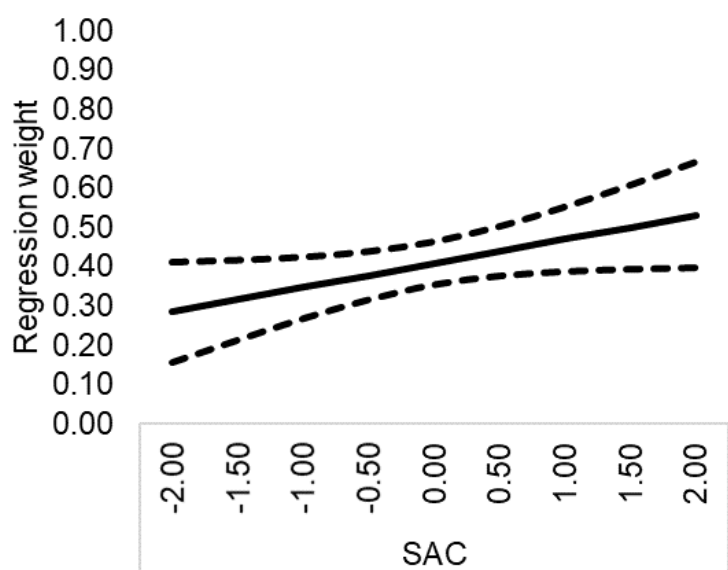

(C) DV = Word-of-mouth intentions and IV = Actual self-congruity

(D) DV = Word-of-mouth intentions and IV = Ideal self-congruity

Figure 1. Estimated regression weights with $95 \%$ confidence intervals as a function of social adjustment concern (SAC), Dependent variable (DV) and Independent Variable (IV) 